\title{
DO PRIVATE PENSIONS INCREASE NATIONAL SAVINGS?
}

\author{
Martin FELDSTEIN* \\ NBER and Harvard University, Cambridge, MA 02138, U.S.A.
}

Received June 1977, revised version received January 1978

This paper discusses how private pension programs differ from public social security in their likely impact on aggregate saving. Although private pensions are likely to reduce direct saving by employees, this should be offset by the combination of companies' partial funding and the shareholders response to unfunded liabilities. In contrast to several earlier empirical studies that implied that social security does depress national saving, the current time series evidence suggests that the growth of private pensions has not had an adverse effect on saving and may have increased saving by a small amount.

\section{Introduction}

Private pensions are now an important source of retirement income in the United States and a significant instrument of government policy. In 1974, some 30 million private employees were covered under some form of private pension plan. In that year, private plans paid some $\$ 12.9$ billion in benefits to 6.4 million retirees and their dependents. ${ }^{1}$

The development of private pensions has been stimulated by favorable tax treatment. The pension contributions made by an employer are a deductible business expense but are not regarded as taxable income to employees until benefits are paid out. The earnings of the pension fund are also allowed to accumulate without the payment of any income tax. When pension benefits are paid out to retirees, the recipients' incomes are generally low so that the tax rates are lower than they were. when the wage income was originally earned. In addition, a special retirement income credit further reduces the effective tax rates on private pension benefits. The U.S. Treasury has estimated that the effect of excluding pension contributions and earnings from individuals' taxable income reduced personal tax collection by $\$ 5.7$ billion in fiscal year $1975 .^{2}$ Since the social security payroll tax (currently at

*Harvard University and the National Bureau of Economic Research. This study is part of the National Bureau's research program in social insurance. I am grateful to Anthony Pellechio for his assistance, to the National Science Foundation and the NBER for financial support, and to participants of the 1977 Tokyo ISPE Conference for helpful comments. The views stated in this paper are the author's own and should not be attributed to the NBER or any other organization.

'For further information, see Skolnik (1976).

${ }^{2}$ See U.S. Senate (1976). 
the rate of 1.1 .7 percent) is also not levied on either pension contributions or benefits, even the $\$ 5.7$ billion understates the magnitude of the subsidy.

One of the central issues in evaluating any public or private pension program is the impact of the program on aggregate saving. Private pension plans in the United States now play a major role in the structure of national saving. The accumulated reserves of the private pensions reached $\$ 192$ billion at the end of 1974 , the latest year for which data is available. ${ }^{3}$ The annual growth of these private pension reserves has averaged 25 percent of personal saving during the decade ending in 1974. The net impact of these private pensions on aggregate saving has received surprisingly little attention. ${ }^{4}$ The purpose of this paper is to analyze the ways in which private pensions may affect total saving and to present some econometric evidence on the relation between pension saving and total personal saving. ${ }^{5}$

Section 2 introduces the notion of the employees' subjective 'total asset accumulation,' defined as the sum of their direct personal saving plus the increase in the value of their prospective pension benefits. Five reasons why the provision of private pensions may increase their 'total asset accumulation' are analyzed. It is often incorrectly assumed that an increase in employees' 'total asset accumulation' implies an increase in aggregate private saving. Section 3 discusses why an increase in employees' 'total asset accumulation' need not increase and may actually have decreased real private saving. The basic reason for this is that much of the increase in the value of prospective benefits is not funded at the time that it is created. The growth of private pensions could therefore induce employees to reduce their direct nonpension savings by more than the amount by which companies and their shareholders increase their saving. The shareholders' limited perception of their companies' additional future pension liabilities is crucial to this explanation. To assess the net effect of pension growth on private saving, section 4 presents econometric evidence based on U.S. aggregate time series data.

\section{The effect of pensions on employees' total asset accumulation}

Although popular discussions often assume that the annual growth in the value of pension funds represents an equivalent increase in national saving, standard economic analysis suggests that the growth of pensions is essentially

\footnotetext{
${ }^{3}$ See Skolnik (1976).

${ }^{4}$ The effect of pensions on the savings of covered workers has been studied empirically by Cagan (1965), Katona (1965), Munnell (1974), and Schoeplein (1970) and discussed more generally by Drucker (1976) and Murray (1968). The full net effect of pensions on aggregate private saving remains largely unexplored.

${ }^{5}$ I have discussed the effect of the public social security pension program in several recent papers [Feldstein (1974, 1976a, 1976b, and 1977a)] and will not deal with this further in the current study.
} 
a change in the form of saving rather than an increase in the total amount. When individuals receive part of their compensation in the form of promised retirement income, they can reduce their other saving by a corresponding amount. More explicitly, if the switch of compensation from wage income to future pension benefits leaves a worker's lifetime budget constraint unchanged, the rational and unconstrained individual does not alter his lifetime consumption plan; direct personal saving is therefore reduced by the present value of the future benefit. This standard view is clearly implicit in all econometric work on personal savings which ignores the growth of pensions. ${ }^{6}$ It is also explicit in the conventional model of the rational response to pension saving that is discussed by Cagan (1965), Munnell (1974), and others.

A closer examination does however suggest five reasons why the taxinduced growth of private pensions may cause employees to change their 'total asset accumulation,' i.e. the sum of their direct saving and the present actuarial value of their pension benefits. Since an increase in such 'total asset accumulation' is a necessary condition for pensions to increase national saving, it is important to consider each of these five reasons. The analysis shows that the effect of private pensions on employees' total asset accumulation is actually ambiguous; direct saving could actually decrease by more than the value of pension benefits.

\subsection{The rate of return on saving}

The favorable tax treatment of pension contributions and pension fund income raises the net rate of return that is available to workers. Since the tax revenue that is lost by this increase in the net rate of return must be raised by increasing other taxes or reducing government spending, the increase in the net rate of return that follows from the tax treatment of pensions can be regarded as a compensated increase. Although it is natural to assume that such a compensated increase in the rate of return causes an increase in desired saving, there are two problems with such an inference.

First, the increased rate of return may apply only to intramarginal saving. Each individual is not free to vary his own pension contribution. If the pension benefit of an individual represents less saving than he would otherwise do, the higher rate of return has no effect on his incentive to save. To the extent therefore that a firm's pension benefits are set at a level that can serve as a 'widely accepted minimum' that individuals are expected to supplement by direct saving, the favorable tax treatment is merely a reward for saving that would have occurred anyway.

\footnotetext{
${ }^{\circ}$ The national income statistics include the pension contributions of employers and employees in personal saving and personal income. Thus pension contributions are regarded as a form of compensation and no distinction is made between pension saving and other personal saving.
} 
Second, even when the opportunity for pension saving can be regarded as raising the marginal rate of return available to the individual, the result need not be an increase in saving. ${ }^{7}$ A compensated increase in the rate of return is equivalent to a compensated decrease in the price of future consumption and, as such, can be expected to increase future consumption. But current saving is the expenditure on future consumption and will only increase if the compensated price elasticity of retirement consumption exceeds one. The effect of the net rate of interest on private saving is thus theoretically indeterminate. Stated somewhat differently, when the pension saving option is effective at the margin, it converts the current income tax to a consumption tax. This raises the current tax on wage and salary income and reduces the future tax on interest and other capital income. Shifting tax liabilities from the future to the present tends to reduce current saving. A compensated increase in the net rate of return that takes this form can raise future consumption and lower future taxes while raising current taxes enough to reduce both current consumption and current saving. This is possible but not necessary; it does however show why an increase in the marginal net rate of return may actually decrease private saving. ${ }^{8}$

It is clear moreover that the substitution of current taxes for future taxes will have an unambiguously adverse effect on private saving if the pension option changes only the intramarginal rate of return. With no change in the rate of return, a compensated change in taxes leaves consumption in each period unchanged. ${ }^{\text {The }}$ increase in current taxes therefore requires a decrease in current saving; the resulting decrease in future income is just equal to the reduction in the future tax liability.

In short, the higher after-tax rate of return made possible by the favorable tax treatment of pension saving may stimulate more total asset accumulation but economic theory does not imply that this is necessarily true or even that it is more likely than the alternative.

\subsection{Pensions as annuities}

A common feature of pension programs is that benefits are provided in the form of an annuity when the participant reaches a prescribed retirement age. Because of the advantages of group purchase and of commitments made a long time before retirement, the pension plans are able to provide annuities on more favorable terms that individuals could buy themselves. The growth of pensions has therefore brought with it an increased use of annuities to

\footnotetext{
${ }^{7}$ The argument of this paragraph is developed more fully in Feldstein (1977b).

${ }^{8}$ Boskin (1977) presents evidence that aggregate private saving does respond positively to higher net rates of return; there are however significant problems of measuring the relevant net rate of return and no attention is given to the growth of private or public pensions.

${ }^{9} I$ ignore the complication of a possible change in labor supply.
} 
finance retirement consumption. This substitution of annuities for conventional retirement dissaving can be expected to alter employees' total asset accumulation but the direction of the change is unclear.

Because the annuity permits the individual to 'use' all of his assets for his own consumption, ${ }^{10}$ the annuity in effect raises the return that the individual obtains for himself on his assets. This is an uncompensated change and therefore, given a positive marginal propensity to save, tends to raise his saving. ${ }^{11}$ But the annuity also eliminates the financial risk associated with living to an old age and this tends to reduce the amount of asset accumulation that the individual will want to do during his preretirement years.

Although it would be useful to examine the interaction of these effects with an explicit model, it seems clear that the net effect of introducing annuities is theoretically indeterminate.

\subsection{Induced retirement}

Pension benefits are generally paid only when a worker retires from his regular job. Although the benefits may also be available if the 'retiree' starts work with a new employer, most workers who leave their regular jobs in order to collect pensions do not start new full-time employment. The wage rates that are available to older workers in such alternative employment are often substantially lower than their previous wage because the individual loses job specific skills, seniority rewards, etc. The availability of pensions that are contingent on retirement can therefore be viewed as generally inducing earlier retirement than would otherwise occur.

Earlier planned retirement should make employees want to accumulate assets (including direct savings and pension benefits) at a faster rate for two related reasons. First, individuals who plan to have a longer retirement period will want to accumulate more assets by the time they retire. Second. with a shorter preretirement period within which to accumulate, total saving per year must be higher to accumulate any given level of assets by the time of retirement. While the earlier retirement also implies that the number of dissaving years will increase relative to the number of saving years, in a growing economy the first two effects will dominate and aggregate saving will rise. ${ }^{12}$

The positive effect of induced retirement on individual asset accumulation will be reduced or reversed to the extent that individuals do not properly anticipate this induced early retirement. To understand this, consider the

\footnotetext{
${ }^{10}$ In an ex ante actuarial sense: that is, the individual need have no unplanned bequest.

't It is more likely to than a compensated change but, for the reasons given above, need not.

${ }^{12}$ For a more complete discussion of induced retirement and saving in the extended life cycle model, see Feldstein (1976a).
} 
extreme case in which an individual plans to retire at age 70 and does no alter his plans when a pension program is introduced at the firm where he works. He reduces his direct personal saving in such a way that his tota asset accumulation (i.e. his direct saving plus the increase in the value of hi pension rights) remains unchanged. However, when he reaches age 65 he decides to accept the pension and retire. In this admittedly extreme case, the unanticipated induced retirement converts the years between ages 65 and 70 from a period of asset accumulation to a period of dissaving. If everyon behaved in this way, induced earlier retirement would reduce aggregat saving. More generally, the effect on saving of induced early retiremen depends on the extent to which the change in retirement is correctly anticipated by individuals and taken into account in their saving decisions.

\subsection{Forced saving}

Private pensions may force individuals to accumulate more assets that they would otherwise choose to do. This is particularly likely for worker with relatively low earnings for whom the public social security progran already provides benefits that are quite high relative to previous earnings For example, a worker who has had the median level of earnings throughou his working life and who retires at age 65 with a dependent wife will nov receive social security benefits equal to 65 percent of his highest year' earnings. ${ }^{13}$ These social security benefits are indexed to keep pace witl inflation. Moreover, since the benefits are untaxed, they replace nearly 8 . percent of lost net income. The replacement rate is even higher for worker: with lower earnings. The Medicare program also provides heavily subsidized health insurance for everyone over age 65 . With such a relatively high leve of public retirement benefits, many individuals may have little desire for additional private retirement saving. Since these individuals would generally find it impossible to borrow against future pension benefits, they are forcec to accumulate more for retirement than they would otherwise prefer.

Although this picture of 'forced saving' is undoubtedly correct for some individuals, it is not clear how important this effect is in the aggregate. The level of private pension benefits is not imposed by the government or se arbitrarily but is chosen by the firm or union in response to what th covered workers prefer. The level of benefits varies not only among firms bu also within firms among groups with different levels of earnings. The tax law that govern pension contributions explicitly permit firms to take socia security into account in setting the pension benefits at each earnings level Although individual preferences at each earnings level are not uniform, thos

\footnotetext{
${ }^{13}$ See the Report of the Consultant Panel on Social Security to the Congressional Research Service. 1976.
} 
who set the pension levels recognize that it is often easier for individuals to supplement pensions by direct saving than to offset pension by dissaving.

The difficulty of offsetting pension accumulation should also not be exaggerated. Individuals often have other savings that can be reduced. In particular, homeowners accumulate equity as house values rise and mortgages are reduced. This form of saving can be reduced by remortgaging a house or, as is not uncommon, by moving into smaller quarters before retirement and using some of the sale proceeds to finance consumption.

\subsection{Unintended saving and incorrect perception}

All of the preceding arguments have been based on the assumption of rational life-cycle saving by individuals who correctly anticipate the size of their pension benefits. It is frequently argued that this is an inappropriate description of household behavior, that saving is based on habit and rule of thumb rather than rational planning, and that pensions therefore increase employees' total asset accumulation without any explicit decision by the covered individuals. Since individuals are very badly informed about the future benefits to which they will be entitled, the argument continues, they are likely to ignore or undervalue these benefits and therefore to end up accumulating more assets (including the value of pension benefits) than they had intended.

Like 'forced saving,' the notion of unintended saving is a correct picture for some individuals but of unknown aggregate importance. Even individuals who appear to decide their saving by arbitrary rules of thumb may adjust those rules in response to pension programs. Although household surveys show that individuals do not know the money value of the future pensions, ${ }^{14}$ this emphasis on specific money values is misplaced. Individuals may have a better idea of how pensions will relate to preretirement income or of how much additional retirement income will be required to achieve their desired standard of living; unfortunately, we have no evidence on these perceptions. Moreover, an incorrect perception of prospective pension benefits should not be equated with an underestimate. Individuals may exaggerate the likely size of their future benefits, ignore the limits on vesting and portability, or belittle the probability of reducing or losing benefits by changing jobs.

\subsection{Microeconomic evidence}

I began this section by noting that the basic theory of rational saving behavior suggests that employees would respond to an increase in private pension benefits by reducing other direct saving by an actuarially equal

\footnotetext{
${ }^{1+}$ See e.g. Katona (1965). This study and other household survey evidence on pensions and saving is discussed below.
} 
amount. The section then discussed five reasons why this one-for-one substitution may not be correct, i.e. why private pensions may change the total asset accumulation of covered employees. Only one of these, the 'forced saving' that occurs when individuals cannot borrow to offset what they regard as excessive pension benefits, has an unambiguous effect on total asset accumulation. Each of the other considerations implies that the growth of private pensions may either increase or decrease the total asset accumulation of the covered employees.

The attempts to resolve this uncertainty by econometric research have unfortunately been severely hampered by the lack of microeconometric data on the pension benefits to which employees are entitled. Empirical studies have been forced to focus on the differences in direct saving between employees who are covered by private pension programs of any size and those who are not covered. The early work of Cagan (1965) and Katona (1965) concluded that covered employees do not reduce their direct saving. In a more recent study using longitudinal panel data, Munnell (1976) found that male employees over age 45 reduce their direct saving markedly when they have private pensions although not by as much as the value of their pension benefits. The econometric evidence is thus subject to unusually great uncertainty.

It seems reasonable to believe at this time, on the basis of the theoretical analysis and the available evidence, that private pensions increase the total asset accumulation of the covered employees but by less than the full actuarial value of the pensions.

\section{Unfunded pensions, shareholder myopia and national saving}

An increase in the total asset accumulation of covered employees is a necessary but not a sufficient condition for the growth of private pensions to raise national saving. The net effect of pensions on national saving depends critically on the response of the companies and their shareholders. This section explains how pensions can raise the 'total asset accumulation' of employees while lowering aggregate private saving.

It is useful to begin with a special case in which aggregate saving remains unchanged. The effect on saving of departing from these special benchmark assumptions can then be examined. In particular, the three assumptions of this special case are: ${ }^{15}$

(1) Correct employee perception. Employees regard the annual increase in the present actuarial value of their future pensions as an equivalent increase in their wealth, i.e. as a component of their total asset

${ }^{15} \mathrm{It}$ is casiest to analyze this case if we disregard the effects of taxes. This simplifies exposition without changing the basic conclusions of the more general case. 
accumulation." Their current wages are therefore reduced below what they would otherwise be by an equal amount.

(2) Constant employees' total asset accumulation. Employees reduce their direct personal saving to keep the sum of this direct saving and the increased value of future pension benefits unchanged.

(3) Full funding. The company maintains a pension fund with assets equal to the present actuarial value of its employees' anticipated pension benefits. The annual contribution to this fund is financed by the reduction in the firm's total wages since, by assumption 1, the reduced wages are just equal to the actuarial value of the newly created benefits.

It is easy to see that these three assumptions imply that the introduction of a private pension has no effect on national saving. The employees keep their 'total asset accumulation' unchanged and therefore reduce their direct saving by the increased value of their pensions. At the same time firms increase their direct saving by the same amount. With full funding, the reduced saving of employees is just sufficient to finance the firms' pension fund saving. Shareholders are indifferent since there is no change in the current or future cost of employee compensation and therefore no change in profits. National saving remains completely unchanged.

In practice, firms do not fully fund their expected future pension benefit payments. Although aggregate data on unfunded future expected benefits are not currently available, the amount is likely to be quite large; some examples will be given below. However, it is important to realize that this lack of pension funding does not in itself imply that private pensions reduce aggregate saving even if employees reduce their own saving by the value of the expected future benefits. If the capital market operates with full information and if shareholders adjust their saving to keep their own wealth unchanged, the reduced saving by employees will be fully offset by the increased saving of firms and shareholders together.

To understand why shareholder saving would just offset the net dissaving of employees and the pension fund, it is useful to retain the first two assumptions of the special case discussed above but to change assumption 3 to:

(3a) No funding. The company has no pension fund. The reduction in the firm's total wages are paid to shareholders as higher dividends.

If the stock market is fully informed, it will recognize that these higher dividends do not represent a permanent increase in the company's profitability but only a postponement of employee compensation. The expected future pension benefits are a liability of the company which should depress the price of the company's shares by an amount that is equal to the present value of the future benefits. Since the extra dividend is equal to the reduction 
in current wages and therefore to the present value of future pension benefits, if shareholders save the entire extra dividend they will maintain their net worth at its original prepension value. This is exactly what they should want to do since nothing has happened to change the real opportunities of shareholders. Note that in saving all of the extra dividends the shareholders exactly offset the fall in the employees' savings; alternatively, the extra saving of the shareholders is like fully funding the future pension benefits. ${ }^{16}$

Although shareholders are undoubtedly aware of their companies' future pension obligations in a general way, they are unlikely to have any precise appreciation of the extent of the unfunded obligation. Such pension liabilities are not reflected in the accounting calculations of corporate balance sheets. Modern accounting practice only requires companies to indicate as a note in their annual report the magnitude of unfunded vested obligations; the total expected unfunded liability need not be reported at all. Vested benefits are defined as those to which employees are entitled even if they leave the service of a company; a company's vested obligation thus inçludes only the actuarial value of the benefits of current retirees plus the value of the benefits that current employees would retain if they terminated employment immediately. Excluded in this calculation of benefit obligations are several components of the expected benefits that employees have already 'earned' but which have not yet become vested, including the past service benefits of employees who are expected to become vested and the increase in future benefits due to past service that will result from future wage increases and years of service. The total unfunded expected liability is likely to be substantially larger than the unfunded vested benefits.

As an indication of the order of magnitude of these obligations, consider the General Motors Corporation. At the end of 1976, GM had pension funds of $\$ 8.1$ billion but the actuarial value of 'vested benefits' exceeded the total value of pension funds by $\$ 3.0$ billion. At the same time, total long-term debt was only $\$ 1.1$ billion. The $\$ 3.0$ billion pension obligation was equivalent to $\$ 10.45$ per share of common stock or 13 percent of the market value of the stock at the end of 1976. Moreover, if unvested benefits have an expected value of only one-half of vested benefits, the unfunded amount rises from $\$ 3.0$ billion to more than $\$ 8.5$ billion; this is equivalent to $\$ 30$ per share at 38 percent of market value. ${ }^{17}$

\footnotetext{
${ }^{10}$ This paragraph shows the important way in which an unfunded (or partially funded) private pension plan differs in theory from an unfunded social security program. With informed capital markets, shareholders will be induced by self-interest to save in a way that offsets the underfunded pensions. The fall in share prices provides the information and incentive to do this. A corresponding offset occurs with social security only if beneficiaries altruistically increase their bequests; see Barro (1974).

${ }^{17}$ The United States Steel Corporation does report both an unfunded liability for vested benefits and a more inclusive 'unfunded accrued liability' for past service. The former is $\$ 4.90$ per share of 10 percent of the market value while the latter is $\$ 14.70$ per share at 30 percent.
} 
In a recent study, Oldfield (1977) used a model of share price determination and a sample of data on individual firms to measure the effect of unfunded liabilities on share prices. He concluded that each dollar per share of unfunded vested liability reduces the share price by approximately one dollar. This implies that share prices are depressed by substantially less than the total unfunded expected future pension benefits. ${ }^{18}$

There is a different and quite indirect kind of evidence that the market undervalues a firm's unfunded pension obligations. Every firm now has the option of funding its pension liability by issuing new bonds and using the proceeds to buy bonds for the firm's pension fund. Although the transaction would only change the form of the firm's obligation from a debt to the employees to an equal size debt to the bondholders, this accounting change would have a substantial tax-advantage for the firm: the interest - cost incurred by the firm on its new debt would be tax deductible while the new interest income received by the pension fund would not be taxed. In the General Motors example referred to above, the $\$ 3$ billion of currently unfunded vested liability could be financed by issuing $\$ 3^{\circ}$ billion of debt; with a 9 percent interest rate, the annual tax saving would be approximately $\$ 135$ million, equivalent to a dividend increase of nearly 10 percent. Why do General Motors and other firms not avail themselves of this opportunity? One plausible explanation is that the market would recognize the explicit debt (and depress share prices accordingly) in a way that the implicit 'debt' to the pension fund is not recognized.

More generally, with the very inadequate information that is available to shareholders about the value of likely future pension payments, it is most unlikely that shareholders increase their own saving to offset the full amount of the unfunded future pension expenditures.

\section{An estimated savings function}

The analysis presented in sections 2 and 3 shows that the effect of the existing private pension program on aggregate private saving depends on the answers to three questions: First, by how much do covered employees reduce their nonpension saving per dollar of present value of anticipated future pension benefits? Second, what fraction of these anticipated future pension benefits do firms currently fund? And, third, to what extent do shareholders increase their current savings to offset the unfunded liabilities of their

\footnotetext{
${ }^{18}$ Oldfield's results must be regarded as preliminary because of an error in his estimation method. In transforming the varfables in an attempt to correct for heteroskedasticity he did not adjust the constant term. His estimation equation therefore corresponds to a different theoretical specification than the one he intended. His actual procedure of deflating by book value is likely to bias the coefficient of the unfunded pension obligation variable towards minus one if it is truly close to zero. Correcting for this bias reinforces the conclusion that share prices do not respond fully to unfunded future pension benefits.
} 
corporations? At this time we do not have good answers to any of these three questions. Moreover, none of these questions can be investigated adequately with the currently available data. It is necessary therefore to go directly to an analysis of the net effect of pension growth on private saving.

The current section presents evidence based on an aggregate private savings equation estimated with annual time series data. The specification of this equation can best be described as an elaboration of the conventional personal savings equation that is suggested by life-cycle and permanent income theories of consumption. In the absence of any public or private pension program, this conventional savings equation could be written:

$$
S P E R_{t}=\beta_{0}+\beta_{1} Y D_{t}+\beta_{2} Y D_{t-1}+\beta_{3} R U_{t}+\beta_{4} W_{t-1}
$$

where $S P E R$ is a real personal saving per capita, $Y D$ is real disposable income per capita, $R U$ is the unemployment rate and $W$ is the real per capita value of wealth. ${ }^{19}$ The level of disposable income in the previous year and the unemployment rate are included in an attempt to approximate permanent income. Additional lagged values of disposable income might be included but are generally not statistically significant.

In a previous paper [Feldstein (1974)], I extended this specification to include 'social security wealth' $(S S W)$, defined as the present actuarial value of the social security benefits which individuals could anticipate being eligible to receive at age 65 , as an additional variable. ${ }^{20}$ Social security wealth decreases personal saving in a way that is analogous to the effect of additional ordinary wealth but its effect is more complex because social security changes retirement behavior and may alter intergenerational transfers. ${ }^{21}$ Another earlier study also showed that personal saving tends to vary inversely with corporate retained earnings [Feldstein (1973)]. This implied tendency of shareholders to take retained earnings into account in deciding their personal saving is of course consistent with theoretical expectations. With the addition of social security wealth per capita and corporate retained earnings per capita, eq. (1) becomes:

$$
\begin{aligned}
S P E R_{t}= & \beta_{o}+\beta_{1} Y D_{t}+\beta_{2} Y D_{t-1}+\beta_{3} R U+\beta_{4} W_{t-1} \\
& +\beta_{5} S S W_{t}+\beta_{6} R E_{t} .
\end{aligned}
$$

${ }^{19}$ This equation is directly analogous to the aggregate consumption function "estimated by Ando and Modigliani (1963); multiplying both sides by minus one and adding $Y D_{r}$ to both sides converts ( 1 ) into the corresponding consumption function.

${ }^{20}$ The specification used in that study was actually the analogous consumption function; see the previous footnote.

${ }^{21}$ These ideas are discussed in Feldstein (1974. 1976a) and more fully in section 1 of Feldstein and Pellechio (1977). 
Since private savings is the sum of personal savings and retained earnings, eq. (2) implies directly that

$$
\begin{aligned}
S P R I V_{t}= & \beta_{o}+\beta_{1} Y D_{t}+\beta_{2} Y D_{t-1}+\beta_{3} R U+\beta_{4} W_{t-1} \\
& +\beta_{5} S S W_{t}+\left(1+\beta_{6}\right) R E_{t},
\end{aligned}
$$

where $S P R I V_{t}=S P E R_{t}+R E_{t}$ is real per capita private savings.

Although private pensions have not yet been referred to explicitly, they are already reflected in the saving and disposable income variables. Personal saving is defined in the national income accounts to include pension saving and disposable income includes employees' contributions to pension funds. A useful way to assess the net effect of pension growth on private savings is to include the annual net pension saving (SPEN) component of personal saving as an addition to the explanatory variables of eq. (3):

$$
\begin{aligned}
S P R I V_{t}= & \beta_{o}+\beta_{1} Y D_{t}+\beta_{2} Y D_{t-1}+\beta_{3} R U+\beta_{4} W_{t-1} \\
& +\beta_{5} S S W_{t}+\left(1+\beta_{6}\right) R E_{t}+\beta_{7} S P E N_{t} .
\end{aligned}
$$

The extreme hypothesis that each dollar of pension saving increases total private saving by one dollar implies $\beta_{7}=1$; I shall refer to this as the Add-on Hypothesis. A second special case, which I shall refer to as the Substitution Hypothesis, is that pension saving has no effect on total private saving, i.e. $\beta_{7}=0$. More generally, the theoretical discussion of 'sections 1 and 2 implies that $\beta_{7}$ is not bounded by zero and one but could in principle be negative (if pensions depress net private saving) or greater than one (if employees do not reduce their own direct saving while firms and shareholders save more because of their future liability).

Eq. (4) has been estimated with annual time series data for the period from 1929 to 1974 , the most recent year for which the necessary pension data is available. The sample excludes the wartime years, 1941 through 1946. The saving, income and retained earnings variables are derived from the recently revised official national income account estimates. The series are published in constant 1972 dollars $^{22}$ and have been divided by the total civilian population to obtain per capita variables. The unemployment rate is the average unemployed percentage of the civilian labor force during the year as reported in the Economic Report of the President for 1977. The wealth series $(W)$ is calculated by linking the estimates of household wealth at market value originally published by Ando and Modigliani (1963) and Evans (1969) for the period 1929 to 1951 with estimates for the more recent period that are developed using the same definitions for the MIT-Penn-SSRC econometric 
model; this series is converted to constant 1972 dollars by deflating with the consumer price index. The social security variable $(S S W)$ is an estimate of the present actuarial value of the future benefits for which current workers and retirees would eventually be eligible; the method of constructing this variable is described in Feldstein (1974). ${ }^{23}$ The retained earnings variable is estimated by the Department of Commerce to be net of economic depreciation at replacement cost and adjusted for inventory valuation profits. ${ }^{24}$ Pension saving (SPEN) is measured as the increase in the book value of pension fund reserves during the calendar year; this is equivalent to the contributions of employers and employees plus investment earnings (excluding capital gains) minus the sum of benefits and the costs of operating the pensions (including the charges of pension fund managers, insurance companies, etc.). ${ }^{25}$ These pension values are also adjusted to real dollars with the consumer price index and converted to per capita amounts.

The parameter estimates for eq. (4) are presented in table 1 as eq. (1.1). The coefficient of the pension saving variable is positive but it is only a small fraction of its standard error. It is clearly not possible to reject the Substitution Hypothesis $\left(\beta_{7}=0\right)$ that private pensions have no effect on total private saving. The large standard error should also serve as a warning that this negative finding should not be interpreted as implying strong evidence that pensions have little effect on private saving; although the coefficient is small, the large standard error implies that the data are also consistent with a rather wide range of possible effects on private saving. The full Add-on Hypothesis $\left(\beta_{7}=1\right)$ can however be unambiguously rejected. Eq. (1.2) shows that dropping the insignificant unemployment rate variable does not affect the finding that the coefficient of the pension saving variable is small and very much less than its standard error.

Private pensions were a relatively unimportant feature of the American economy during the years before World War II. As late as 1945 there were only 6.4 million employees covered by private pension plans; in the next thirty years, the coverage increased five-fold and the real value of pension reserves increased by a factor of twelve. It might well be argued that the response of savings to pensions in the postwar period may therefore be quite different and, at least, deserves separate analysis. The specification of eq. (1.1)

\footnotetext{
${ }^{23}$ The particular variable used in this paper corresponds to GSSW32, i.e. gross social security wealth estimated on the assumption of 2 percent growth and a 3 percent discount rate for future real benefits.

${ }^{24}$ This is a significant improvement over the retained earnings estimates that were available before the recent revision of the national income accounts. Depreciation was then based on 'tax depreciation' and therefore reflected historic costs and artificial depreciation schedules.

${ }^{25}$ In 1974 , contributions were $\$ 25.0$ billion and benefit payments were $\$ 12.9$ billion. The increase in book value of $\$ 11.5$ billion fell short of the difference between contributions and benefits by $\$ 0.6$ billion. Skolnik and Eisner (1959) and Skolnik (1976) are the sources of these data.
} 


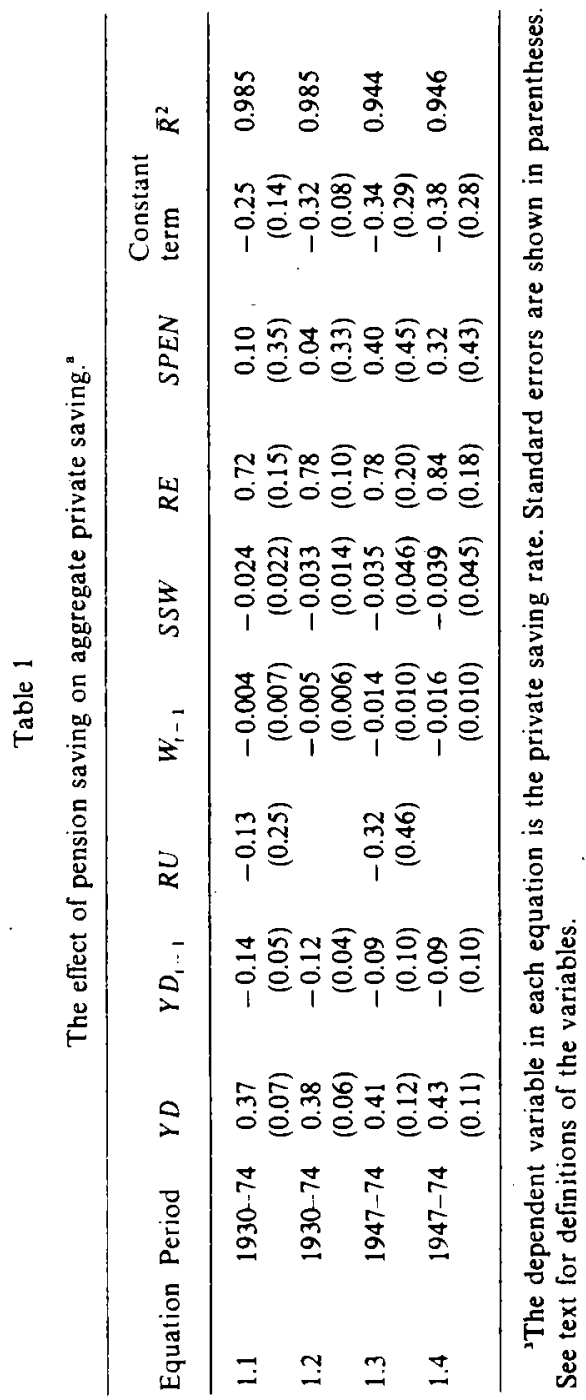


is repeated for the period 1947 through 1974 in eq. (1.3). The coefficient of $S P E N$ is now substantially larger although still smaller than its standard error. This remains true when the unemployment rate is omitted in eq. (1.4).

\section{Conclusion}

The analysis and statistical estimates presented in this paper point to an important difference in the aggregate economic impact of private pension programs and unfunded public social security programs. Although such public social security programs are likely to reduce national savings by acting as a substitute for household retirement saving, this tendency is offset in private pension programs by the combination of the companies' partial funding and the shareholders' response to unfunded liabilities. Of course, neither effect is theoretically unambiguous. The adverse savings effect of social security can be offset by induced retirement, changes in intergenerational transfers, etc. And private pensions could in principle decrease aggregate saving if covered employees reduce their other saving by more than the sum of pension funded accumulation and the induced extra saving of shareholders. These theoretical ambiguities emphasize the need for empirical research. Several earlier studies implied that social security does depress private saving. In contrast, the current paper indicates that the growth of private pensions has not had an adverse effect on saving and may have increased saving by a small amount.

It is important to emphasize that the parameter estimates presented in this paper should be regarded as only a first attempt to answer an important question. This work can usefully be extended in a number of directions. It would, for example, be worthwhile to study alternative measures of pension saving or expected pension benefits. ${ }^{26}$ A measure of private pension 'wealth' analogous to the social security wealth variable also deserves consideration. The changes in retirement behavior during the past 30 years suggest analyzing the interaction between pensions and retirement as determinants of saving. It would of course be even better to develop research that looks behind net savings to the separate effects of pension growth on employee saving, pension fund accumulation, share prices and shareholder saving.

The recent legislative changes in the pension field are likely to increase the growth of private pensions and the fraction of pension obligations that are funded. The impact of these developments on aggregate saving deserves careful analysis.

\footnotetext{
${ }^{26}$ One preliminary attempt to include a measure of expected pension benelits resulted in generally insignificant and implausibly large positive parameter estimates.
} 


\section{References}

Ando, A. and F. Modigliani, 1963, The 'life cycle' hypothesis of saving: Aggregate implications and tests. American Economic Review 53, 55-.84.

Barro, R., 1974, Are government bonds net wealth?, Journal of Political Economy 82, 1095 1117.

Boskin, M.J., 1978, Taxation, saving and the rate of interest, Journal of Political Economy.

Cagan, P., 1965, The effect of pension plans as aggregate savings (National Bureau of Economic Research, New York).

Consultant Panel on Social Security to the Congressional Research Service, 1976, Report prepared for the use of the Committee on Finance of the U.S. Senate and the Committee on Ways and Means of the U.S. House of Representatives (U.S. Government Printing Office, Washington).

Drucker, P., 1976, The unseen revolution: How pension fund socialism came to America (Harper and Row, New York).

Evans, M.K., 1969, Macroeconometric activity: Theory, forecasting, and control: An econometric approach (Harper and Kow, New York).

Feldstein, M., 1973, Tax incentives, corporate saving, and capital accumulation in the United States, Journal of Public Economics 2, 159-171.

Feldstein, M., 1974, Social security, induced retirement and aggregate capital accumulation, Journal of Political Economy 82, 905-26.

Feldstein, M., 1976a, Social security and saving: The extended life cycle theory, American Economic Review 66, 77-86.

Feldstein, M., 1976b, Social security and the distribution of wealth, Journal of the American Statistical Association 71, 800-07.

Feldstein, M., 1977a, Social security and private savings: International evidence in an extended life cycle model, The Economics of Public Services, an International Economic Association Conference volume, M. Feldstein and R. Inman (eds.).

Feldstein, M., 1977b, The rate of return, taxation, and personal savings, mimeo (Economic Journal, forthcoming).

Feldstein, M. and Pellechio, A., 1977, Social security. and household wealth accumulation: New microeconomic evidence, NBER Working Paper 206 (Review of Economics and Statistics, forthcoming).

Katana, G., 1965, Private pensions and individual saving, Survey Research Center, Institute for Social Research, The University of Michigan.

Munnell, A.H. 1974, The effect of social security on personal savings (Ballinger, Cambridge).

Munnell, A.H., 1976, Private pensions and saving: New evidence, Journal of Political Economy 84, 1013-32.

Murray, R.F., 1968, Economic aspects of pensions: A summary report (National Bureau of Economic Research, New York.

Oldfield, G.S., 1977, Financial aspects of the private pension system, Journal of Money, Credit and Banking 1, 48-54.

Schoeplein, R.N., 1970. The effect of pension plans on other retirement saving, Journal of Finance 25, 633-37.

Skolnik, A.M., 1976, Private pension plans, 1950-74, Social Security Bulletin.

Skolnik, A.M. and Eisman, J., 1958, Growth in employee-benefit plans, 1954-57, Social Security Bulletin, 4-14 (table 5, p. 12).

U.S. Department of Commerce, Bureau of Economic Analysis, 1976, Survey of Current Business.

U.S. Senate, Committee on the Budget, 1976, Tax expenditures: Compendium of background material on individual provisions (U.S. Government Printing Office, Washington). 